\title{
Use of Digital Mind Maps in Technology Education: A Pilot Study with Pre-Service Science Teachers
}

\author{
Murat DEBBAG ${ }^{1}$, Baris CUKURBASI ${ }^{2}$, Mustafa FIDAN ${ }^{1}$ \\ ${ }^{1}$ Bartin University, Faculty of Education, Department of Educational Sciences \\ Bartin, Turkey \\ ${ }^{2}$ Manisa Celal Bayar University, Technical Sci. Vocational School, Dep. of Computer Tech. \\ Manisa, Turkey \\ e-mail:mdebbag@bartin.edu.tr,baris.cukurbasi@cbu.edu.tr,mfidan@bartin.edu.tr
}

Received: February 2020

\begin{abstract}
This case study aims at ensuring preservice science teachers to acquire experience by creating paper-based mind maps (PB-MM) and digital mind maps (D-MM) in technology education and to reveal their opinions on these mind mapping techniques. A total of 32 preservice science teachers, enrolled in the undergraduate program of Science Teaching at a university in Turkey, participated in this study. During the first three weeks of the six-week study, participants created PB-MM for certain subjects in science education. For the rest of the weeks, they created D-MM by using Coggle. As data collection tool, a form, consisting of open-ended questions, was used in this study. The obtained results demonstrated that the participants generally reported positive opinions including that mind maps are beneficial and useful tools in reinforcing, assessing and visualizing learning in general, making lessons more entertaining as well as offering ease of use. It was also concluded that students can also use mind maps in teaching of other topics such as "Vitamins", "The Earth and the Universe" and "Systems" in particular, as well as in events like meetings, presentations, brainstorming. Advantages of D-MM were listed as the possibility of adding multimedia material, ease of correction processes and the visual richness, while its disadvantage was listed as experiencing technical problems. PB-MM contribute to psychomotor development of students as well as learning by performing/experiencing. The difficulty in processes such as deleting, editing, etc. and in adding videos and images constitute the restrictions of PB-MM technique.
\end{abstract}

Keywords: digital mind map, interactive learning environment, collaborative learning, teacher education, technology education.

\section{Introduction}

Mind mapping technique and mind map material were developed by Tony Buzan in the late 1960s. Mind mapping is a robust and unique technique to transform all different functions of the brain such as words, imagination, numbers, reasons, images, lists, colors, and rhythm into action (Buzan \& Buzan, 1996; Buzan, Dottino, \& Israel, 2012). In other words, mind mapping associates imagination with structures and images through 
a variety of connections. Within this aspect, it is a tool that increases success in education and contributes to meaningful learning (Brinkmann, 2003). Gelb (1995) states that the information is organized in the mind just like a cobweb during mapping for learning permanence. With its aforementioned characteristics, it is also considered as a critical tool in memory enhancement and creative thinking (Buzan \& Buzan, 1996; Buzan, 2005). In addition it enhances the high order thinking skills such as synthesis, planning, reflection, decision making, and summarization (Zampetakis, Tsironis, and Moustakis, 2007). According to Buzan (2005), the mind mapping is based on words, images and colors. To create a mind map, the key concept is initially put in the center of paper and the sub-ideas are placed around this key concept. The relations of ideas with each other are indicated by several connection arrows. This mapping shows how the human brain deals with various ideas and information (Buzan \& Buzan, 1996).

Researchers have defined the mind mapping technique within the scope of several perspectives. Buzan (2009) defines the mind mapping technique as "the technique of storing, editing and organizing information generally on paper, by means of using key words and key images", while Nast (2012) defines it as "summarizing sets of information on paper". On the other hand, Khoo (2014) describes it as "diagrams explaining connections and interrelations between concepts". It seems that mind maps, as can be seen in the aforementioned definitions, have a different structure from concept maps, although they are frequently confused with concept maps (Buzan, Griffiths, \& Harrison, 2013) in the context of their above-mentioned characteristics and their substitution for each other in some sources (Warwick \& Kershner, 2006). "Mind mapping" as an instructional technique and "mind maps" as a material differentiates from concept maps in terms of their principles of creation, the visual means they contain and map reading forms (Eppler, 2006). Another basic difference between the mapping strategies is that concept maps focus on connections between concepts while such connections in mind maps are established through symbols and signs to facilitate remembering (Nilsson, 2002). The mind maps use to motivate students, perform applications, assess new information, and to connect between concepts etc. in learning environments (Novak, 2009).

When the literature is reviewed, numerous studies are found that its positive educational outputs on the use of paper-based mind maps (PBMMs) in several field such as foreign language (Gomleksiz \& Yetkiner, 2012), science (Balim, 2013; Keskinkilic-Yumusak, 2013; Hidayati, Zubaidah, Suarsini, \& Praherdhiono, 2020), music (Coban \& Selcuk-Tokatli, 2017), social sciences (Karadeniz, Tangulu, \& Faiz, 2013), maths (Ozdemir, Alaybeyoglu \& Filiz-Balbal, 2017), instructional technologies (Aydogdu \& Guyer, 2019). On the other hand, students as today's digital natives often use and prefer digital media, which have been effective in the development of their mind maps and the creation of "interactive mind maps (iMindMap)" in a technological form (Willis \& Miertschin, 2006; Zipp, 2011). Thanks to today's technology and computers, it is possible to create visually more appealing mind maps, which are easier to review, update and store, though with the same purposes and principles as that of PBMMs (Tungprapa, 2015). While relations between concepts are drawn manually on paper or board in PBMMs, the same processes in digital mind maps (DMMs) are performed by drawing the relationships automatically via a computer software (Aljaser, 2017). In this sense, DMMs offer significant innovations 
in terms of technique, such as minimum need for tools, easy sharing, visual richness and portability, and the ability to create and analyze maps with different outlooks (Papushina, Maksimenkova, \& Kolomiets, 2017). The mentioned software provides students with the freedom to use any color and expression and to add any image to their map (Balim, Aydin, Turkoguz, Evrekli, \& Inel, 2011). In addition, the difficulty of making sense of the concepts learned at school and associating them with the new concepts, which is one of the biggest problems faced by students, can be minimized through DMMs. With the mentioned advantages, DMMs can be regarded as an innovative/alternative tool in teaching and a learning technique that can incorporate digital native students.

Coggle is one of the most commonly used Web 2.0 tools for the DMMs. Thanks to its advantages, Coggle has various properties for educational use. It can be operated online on browsers, with a simple and user-friendly interface, enabling users to work in a collaborative and synchronous manner, and allowing storage on the cloud and printouts in a variety of formats (Coggle, 2018). Coggle allows the user to work on mobile devices, while providing partially free content. It can be used both in and out of class and it also allows the user to add interactive-shareable links, videos, graphics, diagrams and images and to make presentations, providing instant messaging opportunity and contains entertaining visual elements, which is easy-to-access for students; these, in addition to the aforementioned features, along with the aforementioned features, these are the determinant factors for the use of Coggle in this study.

In the light of the foregoing information, it is noted that mind mapping technique is not used widely enough by instructors at different instructional levels even if its efficiency is proven (Edwards \& Cooper, 2010). Few studies carried out with preservice science teachers (PSTs) at undergraduate level (Ekici, 2015; Ozcakir-Sumen \& Calisici, 2016). As forementioned, most of studies are related to PBMMs characterized as paper/ pen based in learning environments. DMM tools such as Coggle which are a new technological form than the forms of traditional mind maps. Hence, the number of studies on DMMs is also quite limited in the literature (Chang, Chiu, \& Huang, 2018; Mohaidat, 2018; Papushina, Maksimenkova, \& Kolomiets, 2017). It is considered that the current study differentiates from the previous studies with addressing the DMMs in teacher education and can filled this gap in the field by offering the solid evidences.

\subsection{Purpose of Study}

This case study aims at ensuring preservice science teachers (PSTs) to acquire experience by creating paper-based mind maps (PBMMs) and digital mind maps (DMMs) in technology education and to reveal their opinions on these mind mapping techniques. The questions, which are tried to be answered in this study, are as follows:

1. What are the opinions of PSTs on the use of mind map technique in the learningteaching process?

2. What are the opinions of PSTs who create PBMMs for its use in science education?

3. What are the opinions of PSTs who create DMMs for its use in science education? 


\section{Method}

The case study was employed as a qualitative research method in the study.

\subsection{Participant}

A total of 32 PSTs (7 male, 25 female) were selected for the recent study, ranged in age from 18 to $29(\mathrm{M}=21.83, \mathrm{SD}=1.52)$. The criteria sampling, which is one of the purposeful sampling methods, was used in selection of the participants. In this frame, senior students, enrolled in spring semester of the academic year 2016-2017 in the undergraduate program of Science Teaching at a state university located in north of Turkey, were examined in terms of their ability to meet the following criteria:

- Having a computer, tablet pc or smartphone.

- Having the opportunity to use Internet on their computer, tablet pc or smartphone whenever they wish during out-of-class hours.

- Not being absent from school during the study (except for special circumstances).

- Taking part in the study on a voluntarily.

\subsection{Procedure}

The implementation stage of the study took six weeks within the scope of a course. The PSTs were trained on the use of problem-based learning, LEGO robotics instructional practices, flipped classroom model, and augmented reality in science education. Overall, PSTs created their mind maps for concepts and subjects in learning-teaching processes and use of technology in science education as both individually and cooperatively. In the first stage, they prepared the mind maps in related to the subjects by using PBMMs for the first three weeks.

PSTs were briefed on PBMMs and provided with related examples after the course in the first week; they were informed about the points, which must be taken into consideration while preparing PBMMs. The students were divided into six random groups and prepared by using PBMMs in the classroom (Fig. 1). Then, PSTs were asked to complete their mind maps until the next week's class.

During the course in the second week, the groups introduced their mind maps to other groups. This was followed by the usual class time, in the final part of which the PSTs prepared PBMMs as in the first week. The second week's process was also repeated in the third week. Some of the PBMMs examples prepared by the PSTs are shown in Fig. 2. At the end of first stage, data were collected for the PBMMs implementation process (20 minutes).

Following the stage, DMMs was also applied for the last three weeks of the implementation stage. As a DMMs tool, Coggle was introduced to the PSTs in the fourth week. They were informed about how Coggle is used, how they can work in groups, and how they can use the DMMs prepared by them, by means of supporting examples. Then, the same groups were asked to create DMMs on Coggle. The groups started the 
activity until the end of class time. As in the first three weeks, they were re-asked upon the end of class to complete their mind maps, which they had started creating, until the next week's class (Fig. 3).

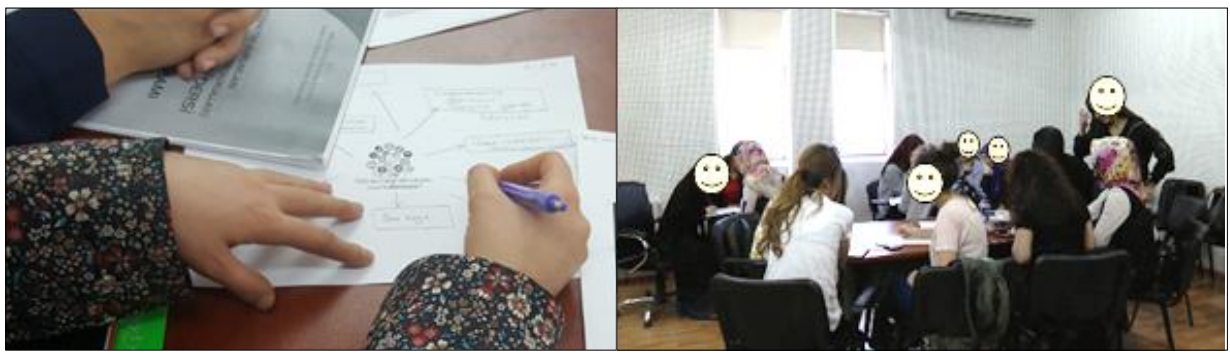

Fig. 1. Images from PBMMs Preparation Studies.

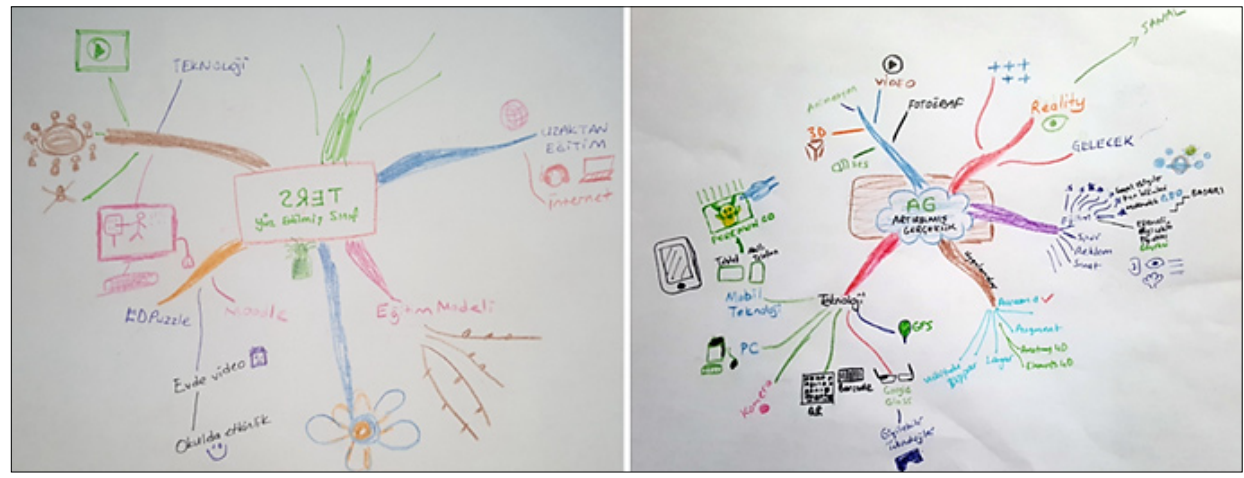

Fig. 2. Examples of Prepared PBMMs Studies.

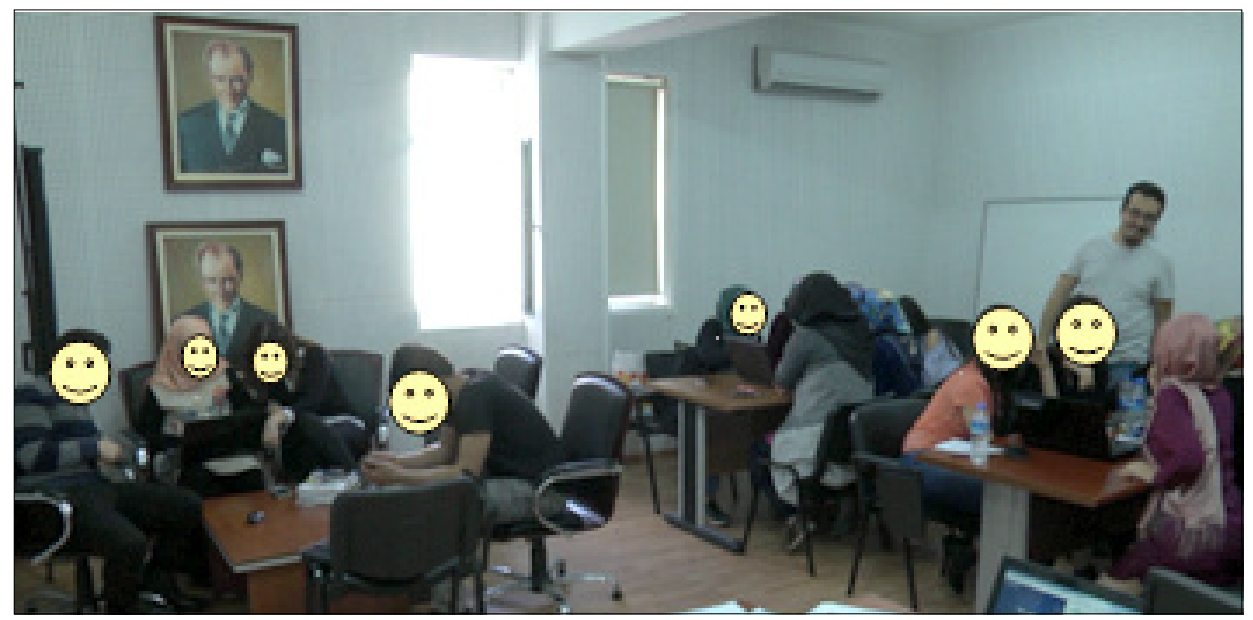

Fig. 3. Images from DMMs Preparation Studies. 
The process carried out in the second and third weeks of implementation was also maintained in a similar way in the fifth and sixth weeks; Coggle was used to create the DMMs. Some of the DMMs examples prepared by the PSTs are shown in Fig. 4.

After the second stage, the PSTs were asked to fill out a second form consisting of open-ended questions (Filling up of these questionnaire forms took 30 minutes on average). In the light of this information, Fig. 5 shows all of the implementation stages of study in detail.

A total of 32 PSTs ( 7 male, 25 female) were selected for the recent study, ranged in age from 18 to $29(\mathrm{M}=21.83, \mathrm{SD}=1.52)$. The criteria sampling, which is one of the purposeful sampling methods, was used in selection of the participants. In this frame, senior students, enrolled in spring semester of the academic year 2016-2017 in the undergraduate program of Science Teaching at a state university located in north of Turkey, were examined in terms of their ability to meet the following criteria:

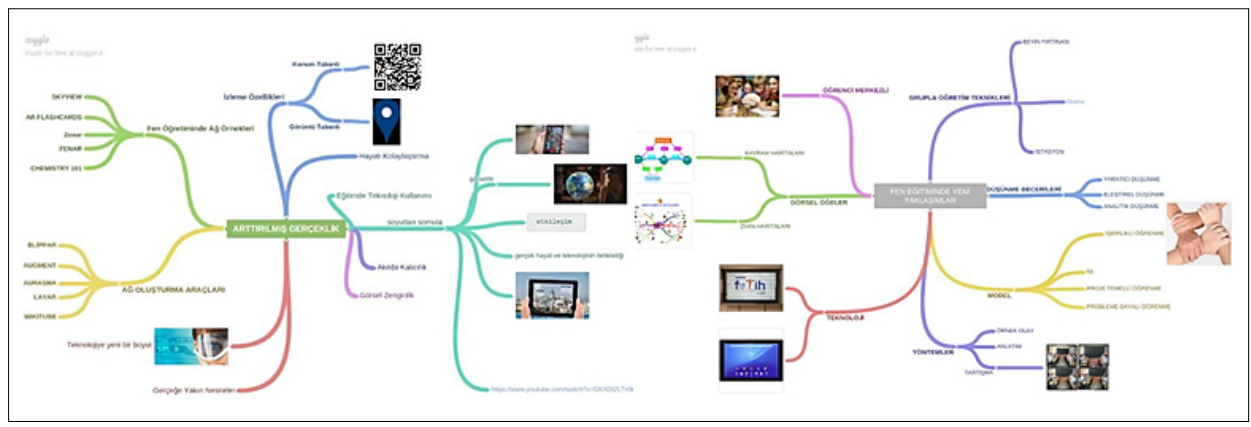

Fig. 4. Examples of Prepared DMMs Studies.
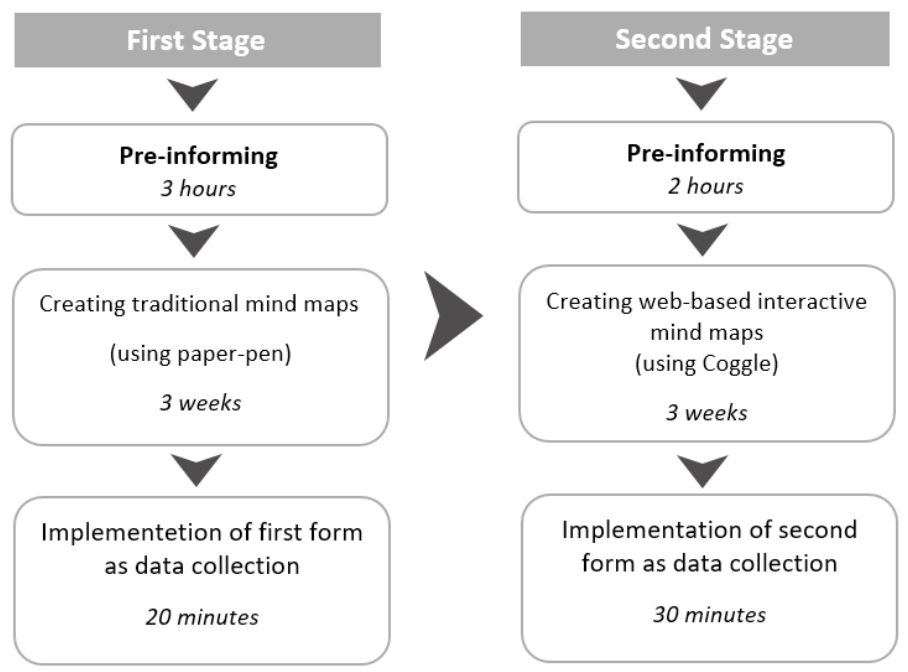

Fig. 5. Implementation Stages of Study. 


\subsection{Data Collection Tool and Analysis of Data}

As data collection tool, two forms were prepared by the researchers. First form includes two open ended questions regarding only PBMMs and generally the mind maps. The open-ended questions in the first form are as follows:

1. What are your opinions on using mind maps in the learning-teaching process?

2. What are your opinions on PBMMs preparation?

On the other hand, there are four open ended questions regarding the DMMs. Opinions of five experts were received for the form's items prepared as draft, and then the items were edited, as applicable. After, PSTs were asked to explain their opinions in detail.

The open-ended questions in the second form are as follows:

1. What are the first expressions that come to mind after the preparation of DMMs?

2. What are the opinions of PSTs regarding on which subjects or for what purpose they can create mind maps through DMMs in science class and other fields?

3. What do you think about educational differences between making the mind map with DMMs or PBMMs?

Descriptive and content analysis were used for data analysis. Content analysis was conducted for the first three sub-problems. Opinions were analyzed and examined within the scope of content analysis; they were then divided into codes and themes. The codes in the tables are arranged from top to bottom according to their frequency. Descriptive analysis was also used for the analysis of the last two sub-problems. The answers given by the participants were grouped and their frequency values were calculated, after which the resulting answers were shown by a word cloud. Examples of statements made by PSTs are provided while explaining the findings. Each participant was given a code to indicate, to which PSTs the examples belong. (Female PT $1=$ FPT1, Male Preservice Teacher $1=$ MPT1, etc.)

\subsection{Validity and Reliability}

Researchers were in communication-interaction with the PSTs in every stage of the study. Before the research process started, lectures were held on regular basis for two weeks, and communication-interaction was established with the students. Expert opinions were consulted at each stage, as deemed necessary in the research process. The research was directed in line with the expert opinions received.

The data were analyzed separately by three researchers, whereby the results of analysis were compared in terms of consistency. This value was calculated as $85 \%$ according to the formula of agreement percentage as referred to by Miles and Huberman (1994). This value indicates that the study has acceptable reliability. 


\section{Result}

\subsection{Findings on the Opinions of PSTs Regarding the Use of Mind Maps} within the Learning-Teaching Process

Upon the study performed, the findings obtained on the opinions of PSTs on the use of mind maps in the learning-teaching process are given in Fig. 6.

Examining Fig. 6, the PSTs mostly reported positive comments on the instructional benefits of the mind maps in particular; on the other hand, there are some negative

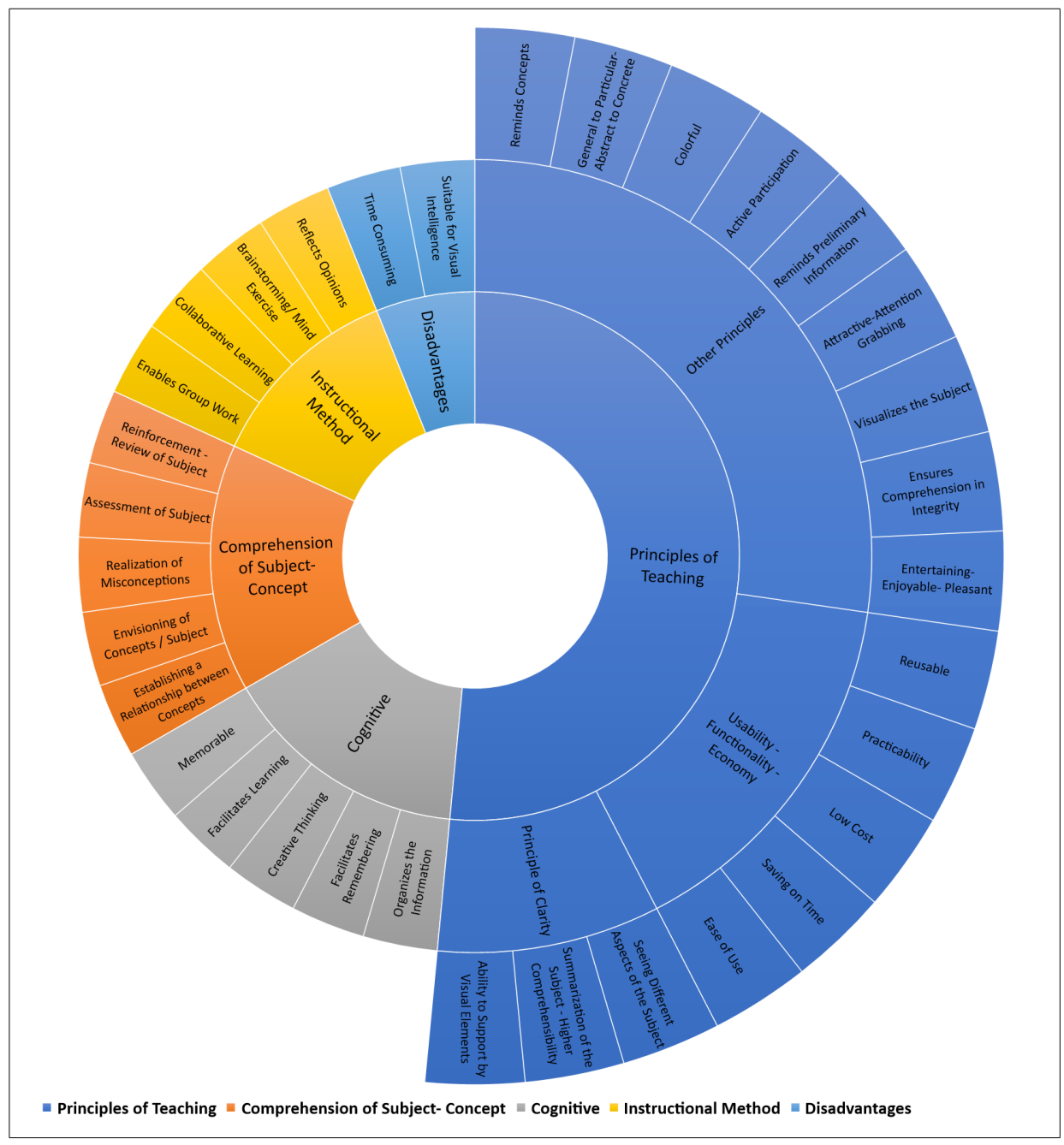

Fig. 6. Opinions on the Use of Mind Mapping During Learning-Training Processes. 
comments, as well. With regard to the activities performed by using mind maps, some of the statements provided that are related to the cognitive process, such as 'memorable' and 'facilitates learning', also related to learning of subjects concepts such as 'opportunity for review-reinforcement of the subject' and 'assessment of the subject' were commonly reported by the PSTs. In addition to the foregoing, it was concluded that the comments related to principles of teaching were frequently stated by the PSTs, including that 'it is easy and fun-pleasant to prepare and use mind maps', 'mind maps are attractive and attention grabbing for students', 'mind maps visualize the subject and allow students comprehend the subject in integrity'. Moreover, the findings obtained include other opinions, along with that mind maps are available for use for learning activities such as brainstorming, collaborative learning and group work; that preparation of mind maps by very few PSTs $\mathrm{N}_{\text {Negative }}=2$ ) is time consuming, and that preparation of mind maps requires an additional preliminary preparation.

Below (Fig. 7) are some of the statements made by the PSTs on the use of mind maps in the learning-teaching process.

The PSTs were asked which DMMs or PBMMs technique they would choose for using after they start working as a teacher. 20 PSTs stated that they would choose $\left(\mathrm{N}_{\text {DMMs }}=20\right)$ DMMs, while 5 stated that they would choose $\left(\mathrm{N}_{\text {PP-MM }}=5\right)$ PBMMs. 7 PSTs stated that they would use both techniques $\left(\mathrm{N}_{\text {Both }}=7\right)$.

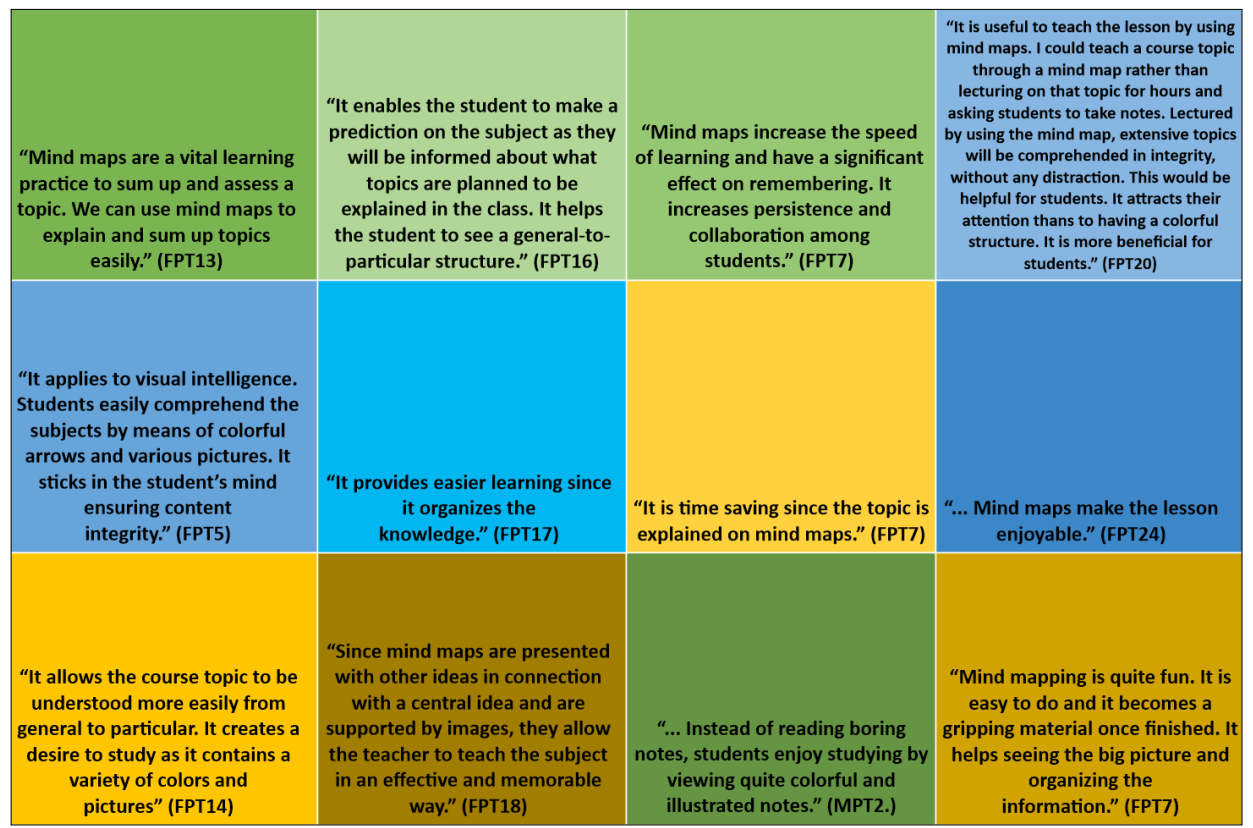

Fig. 7. Some of The Statements Made by The PSTs on The Use of Mind Maps in The Learning-Teaching Process. 


\subsection{Findings about the Opinions on the Preparation of PBMMs}

Upon the study performed, the findings obtained on the opinions of PSTs on the preparation of PBMMs are given in Fig. 8.

Examining Fig. 8, it can be seen that the PSTs' comments on the preparation of PBMMs mainly included their opinions on the disadvantages of PBMMs, such as that 'deleting-correcting is difficult when there is a mistake', 'it is impossible to add videos' and 'it is impossible to use all types of visual elements'. Furthermore, there are also comments by the PSTs addressing the instructional advantages of PBMMs, such as that

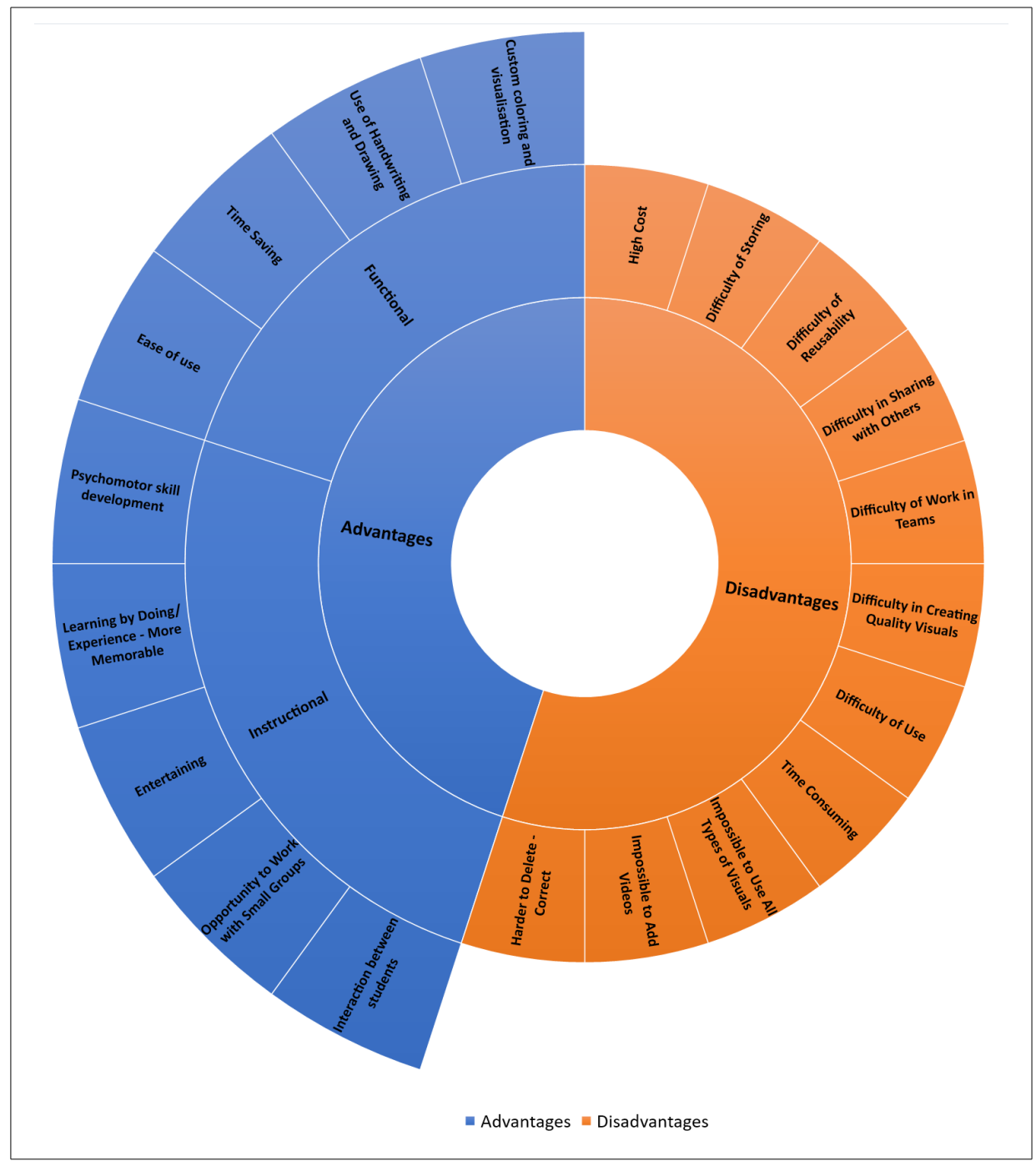

Fig. 8. Opinions on the Preparation of PBMMs. 
"Mind mapping allows access to a higher number of people when they are prepared by using technology. Performing the activity manually would be an activity with small groups." (FPT6)

"It is much costlier with cardboard, glue, printouts and other items. Also, fewer number of resources can be reached. ... In case of making a mistake, the process is repeated from the beginning and this may be exhausting." (FPT13)
"Manual activity may involve hand drawing with colored pencils, but it is significantly time consuming. However, when preparing it technologically, we can find the visual elements at the same time and place them into our mind map. Using videos as visual elements is also among the advantages of mind mapping by using

technology. .... When we make a mistake in a manually prepared mind..

"When considered within the classroom environment, manually created mind maps are more educational and more memorable than mind maps created by using technology. Both provide thinking skills, remembering, persistence, comprehension of the subject in integrity, and visualization. But I think that manually prepared mind maps make the lesson enjoyable and ensure persistence, as the branching drawn by hand are colored, they can be colored and shaped according to personal...

Fig. 9. Some of The Statements Made by The PSTs on The Preparation of PBMMs.

'it will contribute to psychomotor skill development', 'it will allow students to experience learning by doing' and the functional advantages of PBMMs such as that 'custom coloring and visualization is possible'. Above (Fig. 9) are some of the statements made by PSTs on the preparation of PBMMs:

\subsection{Findings about the Opinions on the Preparation of PBMMs}

The findings obtained following the study, on the opinions of PSTs regarding the preparation of DMMs are given in Fig. 10.

As seen in Fig. 10, the PSTs made significantly positive opinions on the preparation of DMMs. With regard to the technological advantages of DMMs, a large number of comments were made including, for example, that it allows adding multimedia materials' primarily including video, 'it is easy to prepare, deleting- correction is easy when there is a mistake, and the mind map can be easily stored and reused'. Moreover, the main instructional contributions of the DMMs as stated by the PSTs include that the mind map prepared 'will have visual richness' and 'students can work collaboratively without being restricted to any place'. In addition, very few numbers of PSTs $($ Nnegative $=3$ ) reported that drawbacks may be experienced due to technological problems and failures. Below (Fig. 11) are some of the statements made by PSTs on the preparation of DMMs: 


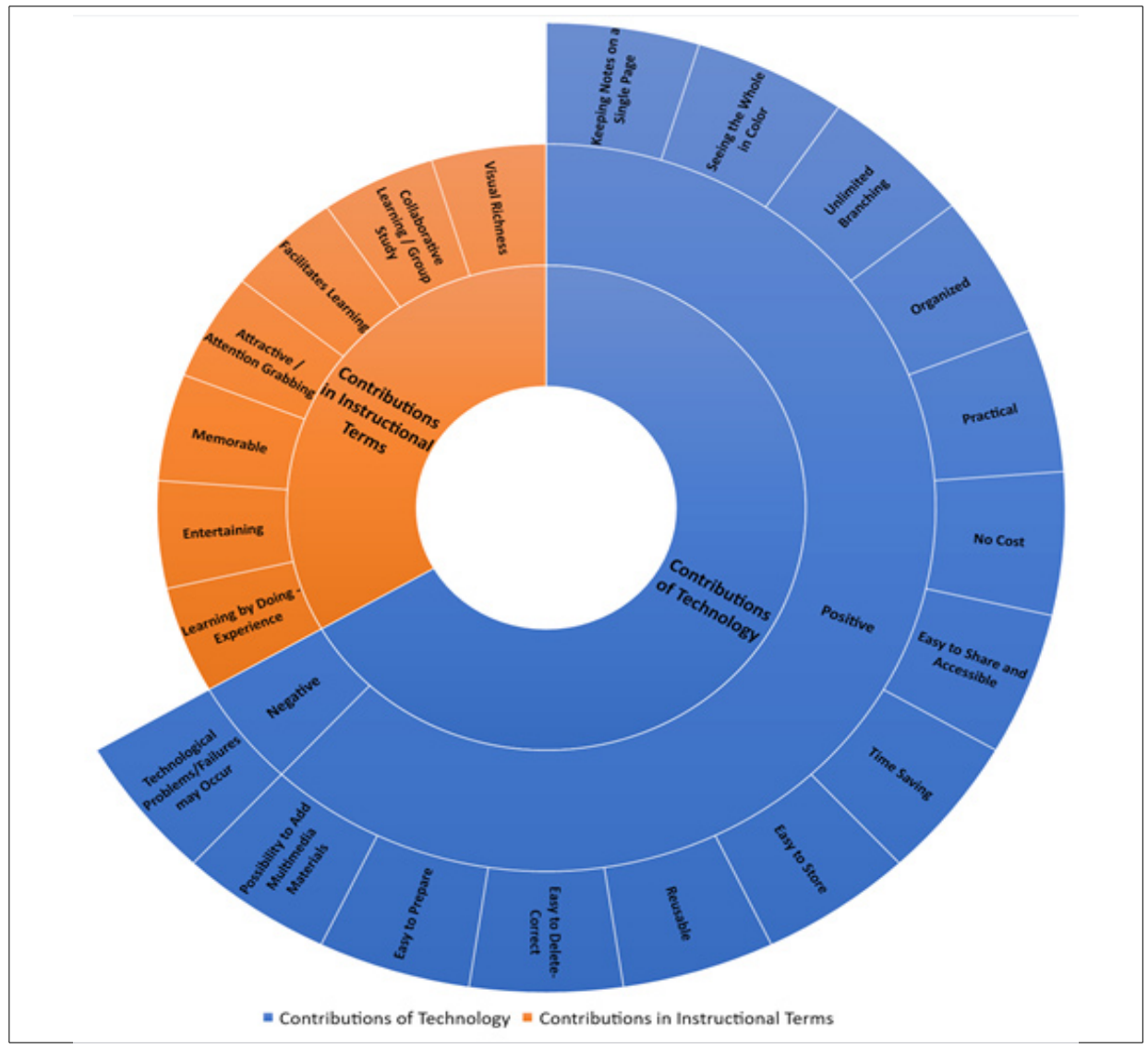

Fig. 10. Opinions on the Preparation of DMMs.

\begin{tabular}{|c|c|c|}
\hline $\begin{array}{l}\text { "I think that the best way of } \\
\text { learning is to reinforce a } \\
\text { concept with images and videos } \\
\text { and to use videos / visual } \\
\text { elements related to the } \\
\text { topic." (MPT1) }\end{array}$ & $\begin{array}{l}\text { "In instructional terms, } \\
\text { Coggle application is } \\
\text { more practicable in the } \\
\text { mind map. Students } \\
\text { will be able to add, for } \\
\text { example, an animation, } \\
\text { video or image, while } \\
\text { also having the }\end{array}$ & $\begin{array}{l}\text { ".... It is easier to use as } \\
\text { it can be integrated to } \\
\text { software such as } \\
\text { PowerPoint and Word } \\
\text { with various slides. It is } \\
\text { quick and easy to }\end{array}$ \\
\hline & $\begin{array}{l}\text { collaboratively, delete } \\
\text { mistakes and see the } \\
\text { whole in color." (FPT2) }\end{array}$ & $\begin{array}{c}\text { prepare with images } \\
\text { and color } \\
\text { options." (MPT3) }\end{array}$ \\
\hline $\begin{array}{l}\text { "When it is created by using } \\
\text { technology, requests can be } \\
\text { sent to colleagues at the same } \\
\text { time to create a collective } \\
\text { output." (FPT7) }\end{array}$ & \multicolumn{2}{|c|}{$\begin{array}{l}\text { "The mind map prepared on a software like Coggle is } \\
\text { visually more appealing in terms of text layout. For } \\
\text { example, coloring or adding suitable pictures to the } \\
\text { subject can help us expand the scope of the mind map. } \\
\text { Additionally, we can see the arrows more clearly in the } \\
\text { mind map prepared on the software. It is difficult to } \\
\text { prepare them in manual mind maps. Technology makes } \\
\text { such tasks easy." (FPT5) }\end{array}$} \\
\hline
\end{tabular}

Fig. 11. Some of The Statements Made by The PSTs on The Preparation of DMMs. 


\subsection{Findings on the First Opinions Regarding DMMs}

The PSTs were asked to write down the first five statements that come to their mind in relation to DMMs. Answers given by the PSTs were grouped and their frequency values were calculated. Then the data given are schematized by a word cloud. An illustration by word cloud is given in Fig. 12.

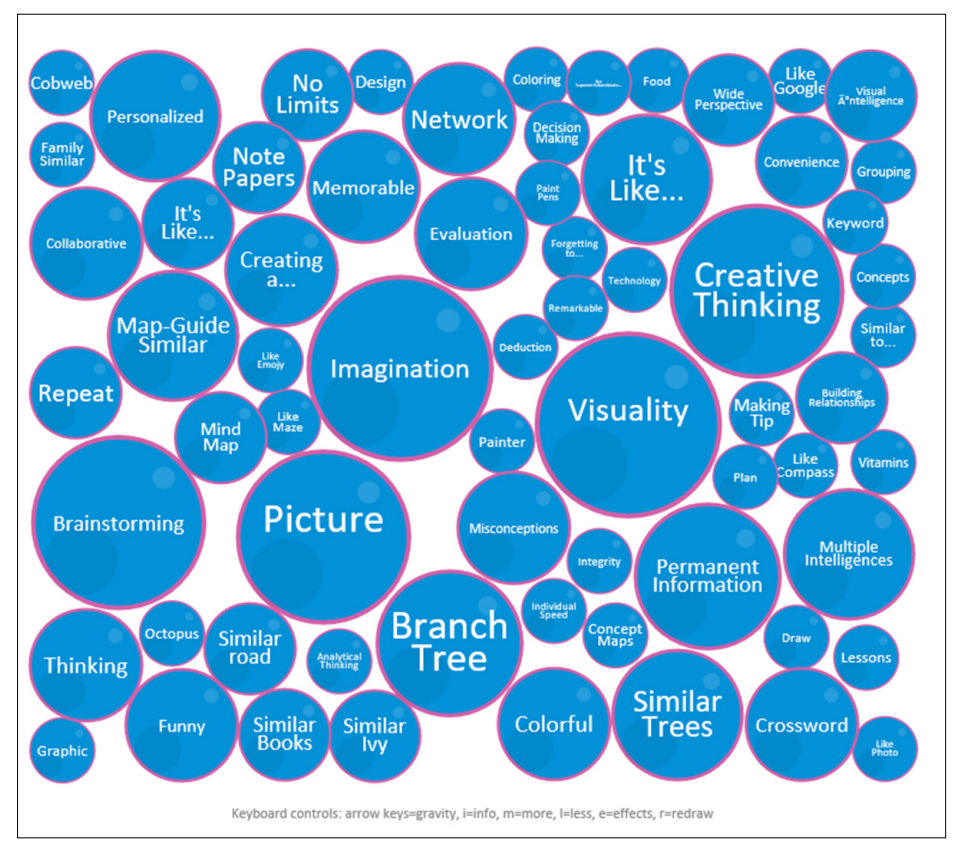

Fig. 12. Word Cloud for The First Expressions That Come to Mind Regarding WT-IMM.

\begin{tabular}{|c|c|c|c|}
\hline $\begin{array}{l}\text { "Visuality is the most } \\
\text { striking feature of } \\
\text { the mind } \\
\text { map." (MPT2) }\end{array}$ & $\begin{array}{l}\text { "Associating pictures } \\
\text { with concepts etc. } \\
\text { will improve } \\
\text { imagination." (FPT3) }\end{array}$ & $\begin{array}{l}\text { "Students perform } \\
\text { brainstorming when } \\
\text { they create mind } \\
\text { maps in } \\
\text { groups." (FPT1) }\end{array}$ & $\begin{array}{l}\text { "It contributes to } \\
\text { creative } \\
\text { thinking." (MPT2) }\end{array}$ \\
\hline $\begin{array}{l}\text { "Visuality is the most } \\
\text { striking feature of } \\
\text { mind maps as they } \\
\text { recall concepts in } \\
\text { mind." (MPT3) }\end{array}$ & $\begin{array}{l}\text { "During mind } \\
\text { mapping, we write } \\
\text { down the products of } \\
\text { our } \\
\text { imagination." (FPT6) }\end{array}$ & $\begin{array}{l}\text { "Any idea that comes } \\
\text { to mind." (MPT6) }\end{array}$ & $\begin{array}{l}\text { "Everyone can do it } \\
\text { differently." (MPT5) }\end{array}$ \\
\hline $\begin{array}{l}\text { "Students will be } \\
\text { able to learn more } \\
\text { quickly." (FPT12) }\end{array}$ & $\begin{array}{l}\text { "We reveal our } \\
\text { imagination in our } \\
\text { mind." (FPT8) }\end{array}$ & $\begin{array}{l}\text { "An individual has to } \\
\text { use creativity to } \\
\text { create a mind } \\
\text { map." (MPT4) }\end{array}$ & $\begin{array}{l}\text { "The first thing that I } \\
\text { see will attract my } \\
\text { attention." (FPT13) }\end{array}$ \\
\hline
\end{tabular}

Fig. 13. Some of The Statements Made by The PSTs in Relation to The Mentioned Findings. 
As can be seen in Fig. 12, PSTs most commonly used the expression Visuality and Imagination between 47 different expressions they stated in relation to DMMs. Additionally, the expressions Brainstorming, Picture and Creative Thinking were commonly stated by the PSTs. Above (Fig. 13) are some of the statements made by the PSTs in relation to the mentioned findings.

\subsection{Findings on the Classes and Topics, Within the Scope of Which the DMMs Can Be Used}

The PSTs were asked for which topics or for what purpose the DMMs could be used in Science class and other classes. The names of topics given by the PSTs for the Science class were grouped, their frequency values were calculated and analyzed by word cloud. PSTs mostly wrote more than one topic. Every topic written was included in the analysis. An illustration by word cloud of the answers given by the PSTs is given in Fig. 14.

As seen in Fig. 14, most of the PSTs stated that the DMMs can be used for all topics in Science class. Nevertheless, the topics "Vitamins", "The Earth and the Universe" and "Systems" were particularly emphasized among 36 different topics stated by the PSTs $\left(\mathrm{f}_{\text {ScienceClass }}=120\right)$. Additionally, the answers given by the PSTs for which topics or purposes the DMMs can be used other than the Science class were similarly analyzed and shown by word cloud in Fig. 15.

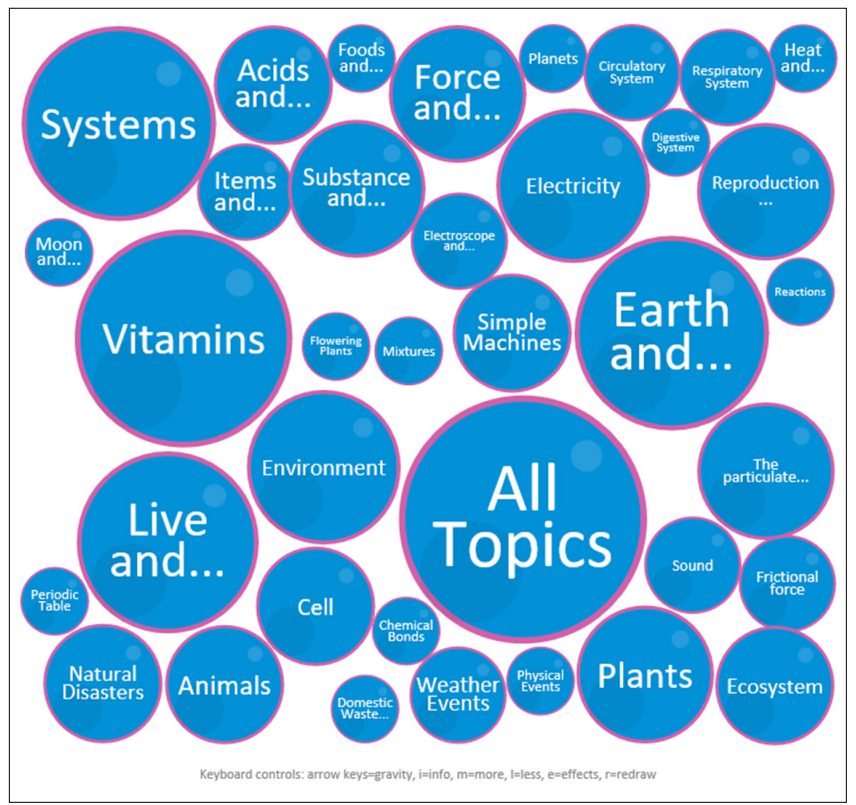

Fig. 14. Schematic Display of Science Course Subjects, Where WT-IMM Can Be Used. 
As shown in Fig. 15, most of the PSTs stated that they would use the DMMs for their Meetings, Seminars and Presentations. On the other hand, the most commonly stated comments included that they could prepare their own Resumes, Brainstorming and Perform Review of Topics by using the DMMs. Below (Fig. 16) are some of the statements made by the PSTs in relation to the fifth sub-problem:

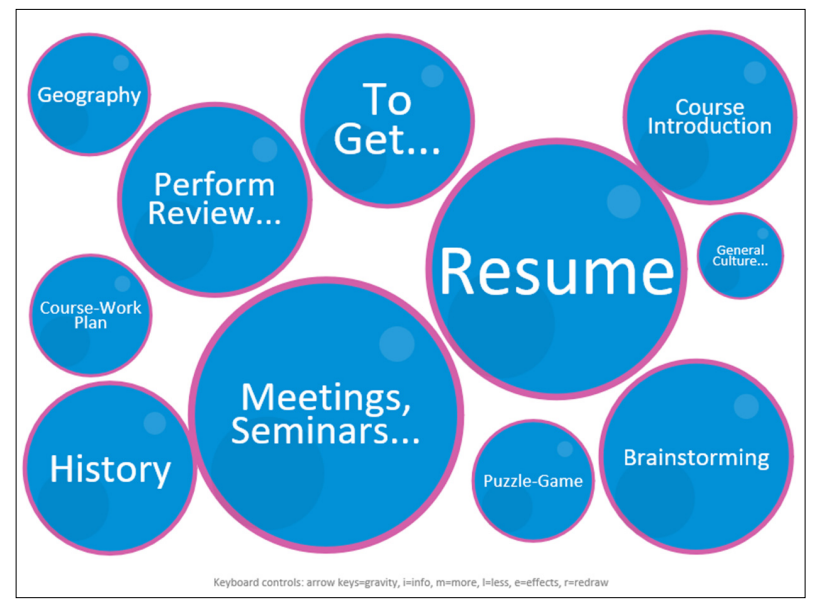

Fig. 15. Schematic Display of Non-Science Course Subjects or Purposes of Use, Where WT-IMM Can Be Used.

\begin{tabular}{|c|c|c|c|c|}
\hline \multirow{2}{*}{$\begin{array}{l}\text { "It will be quite helpful to } \\
\text { use it in Science class as it } \\
\text { allows us to record the } \\
\text { information more easily by } \\
\text { visual memory and the } \\
\text { recorded information will } \\
\text { be memorable over the long } \\
\text { term. As the Science class } \\
\text { refers to numerous visual } \\
\text { phenomena, experiments, } \\
\text { materials, everyday events } \\
\text { will all have a reminiscent } \\
\text { function in the mind } \\
\text { map." (MPT3.) }\end{array}$} & \multicolumn{2}{|c|}{$\begin{array}{l}\text { "For example, we can learn } \\
\text { about the sultans of the } \\
\text { Ottoman Empire by using mind } \\
\text { maps, and easily keep them in } \\
\text { our minds." (MPT1) }\end{array}$} & \multicolumn{2}{|c|}{$\begin{array}{l}\text { "When ideas emerging as a } \\
\text { result of brainstorming are } \\
\text { recorded through mind } \\
\text { mapping, those that are in } \\
\text { support of or linked to each } \\
\text { other can be easily } \\
\text { seen." (FPT1) }\end{array}$} \\
\hline & \multirow{2}{*}{\multicolumn{3}{|c|}{\begin{tabular}{c|c} 
& $\begin{array}{c}\text { "We can also use } \\
\text { the mind map by } \\
\text { playing games out } \\
\text { of the class. For }\end{array}$ \\
'After the lecture on & $\begin{array}{c}\text { example, we can } \\
\text { a topic, students } \\
\text { can be asked to } \\
\text { create a mind map } \\
\text { collaboratively on an adequately } \\
\text { branched web } \\
\text { Coggle in order to } \\
\text { measure what has } \\
\text { around concept } \\
\text { remained in their } \\
\text { mind." (FPT25) }\end{array} \quad \begin{array}{c}\text { game played in } \\
\text { rotation with }\end{array}$ \\
students." (FPT4)
\end{tabular}}} & \multirow[b]{2}{*}{$\begin{array}{l}\text { “Mind map can be } \\
\text { used to introduce } \\
\text { occupations. We } \\
\text { can view Turkey in } \\
\text { as region and } \\
\text { province based. We } \\
\text { can use it in } \\
\text { geography and } \\
\text { history } \\
\text { classes." (FPT21) }\end{array}$} \\
\hline $\begin{array}{l}\text { "For example, when we } \\
\text { think about electricity, } \\
\text { we can branch out } \\
\text { concepts and pictures } \\
\text { that come to our mind. } \\
\text { Such concepts and } \\
\text { pictures can as well be } \\
\text { branched out among } \\
\text { themselves." (FPT7) }\end{array}$ & & & & \\
\hline
\end{tabular}

Fig. 16. Some of The Statements Made by The PSTs in Relation to The Fifth Sub-Problem. 


\section{Discussion and Conclusion}

The aim within the scope of the study is to ensure PSTs to gain experience on creating PBMMs and DMMs through a six-weeks application and compare to opinions of the participants on these mind maps. In this context, the following conclusions have been reached under the study:

Regarding mind maps, the PSTs usually stated their opinions on their instructional benefits, including their relevance to principles of teaching, their contributions to cognitive process and teaching of subjects-concepts, and their availability for use as a teaching method. The other opinions commonly stated are that mind maps are more memorable; they facilitate learning process and provide an opportunity to reinforce review subjects. The studies found upon literature reviews are observed to have similar results (Erdem, 2017; Hallen \& Sangeetha, 2015; Kansizoglu, 2014; Keles, 2012; Krasnic, 2011; Liu, Tong \& Yang, 2018; Madu \& Metu-Ifeoma, 2012; Ziyadi \& Surya, 2017; Hidayati et al., 2020).

The literature comprises a number of negative comments on PBMMs, such as that it is hard to illustrate complicated relationships and to interpret, and that it is not possible to create clear, precise associations between ideas (Kansizoglu, 2014), as well as a number of positive comments such as that it ensures visual organization and integration of the information (Mapman, 2013); it provides a field of view at a high and low level; it is attention grabbing and based on interaction (Krasnic, 2011). During the study, it was observed that the PSTs usually evaluated the PBMMs and DMMs through comparison as they used both techniques in the implementation process, and that they stated opinions on disadvantages and advantages of PBMMs compared to DMMs. The most stated opinions among all are that it is hard to delete - correct errors on PBMMs, and it is impossible to add videos and to use all types of visual elements. Erdem (2017) noted that the difficulty in finding suitable visuals and symbols makes it difficult to visualize the scheme in mind. Additionally, it was observed that there are positive opinions such as that PBMMs contributes psychomotor skill development of students and their learning by doing- experience, and it can be customized by paper and pen. Therefore, this is consistent with the opinions in the literature, stating that PBMMs is a suitable tool for the learner-centered active learning environment (Rosciano, 2015; Willis \& Miertschin, 2006). It was observed that most of the negative comments made by the PSTs on PBMMs arises from the additional opportunities provided by the DMMs creating tool for users compared to PBMMs. Hence, the study by Boyson (2009) suggests the use of DMMs as it helps students to organize/arrange their ideas more easily at the mind mapping stage. Whereas, Nong, Pham and Tran (2009) indicate that DMMs is more effective in terms of illustration of relationships between concepts and collaborative works.

Regarding DMMs, the PSTs mostly reported opinions on the advantages of the DMMs creating tool used. In this context, the most stated comments were that it is possible to add multimedia materials primarily including videos, mistakes can be easily deleted- corrected and it is easy to prepare. Similar studies conducted reveal that positive conclusions were reached on the ease of use and interactive features of the 
DMMs (Chang, Chiu, \& Huang, 2018); it is easy to delete-correct mistakes, it is easy to build relationships between concepts, and pictures and schemes can be quickly added (Aljaser, 2017; Jbeili, 2013). Furthermore, the PSTs addressed the instructional contributions of the DMMs such as visual richness, and collaboration- group work without place restrictions. DMMs allows students to perform a real time collaborative work (Jbeili, 2013; Nong, Pham, \& Tran, 2009; Williams, 2012), which contributes to creative problem solving in addition to developing collaboration (Amin, 2005; Shih, Nguyen, Hirano, Redmiles, \& Hayes, 2009). On the other hand, very few PSTs stated that web-based activity may be interrupted by possible technological problems or failures. Upon literature review, no result addressing technological problems was found. Nevertheless, most of the PSTs stated that they would use the DMMs in their teaching career. Although the literature contains many studies addressing positive opinions on the DMMs, no study revealing preferences of the PSTs was found.

It was seen that the first expressions that came to minds of PSTs about DMMs after their experience with the DMMs were as follows: visuality, imagination, picture and creative thinking. This finding is consistent with the studies confirming that mind maps improve students' imagination and creativity (Bilasa, 2015; Wang, Lee, \& Chu, 2010); and that they activate learners' visual and verbal symbolic systems (Beydogan, 2011).

They indicated that an DMMs can be created by using DMMs for almost all topics in Science class, primarily including vitamins, the earth and the universe. The study by Gomleksiz and Fidan (2013) generally employed the computer-aided mind mapping technique and revealed that there was a positive progress in the students' attitude towards Science class, which are similar to the finding above. Similarly, the study by Babaoglu and Keles (2018) on the topics of the earth, the moon and the sun for sixth grade students lead to the conclusion that students expressed astronomy concepts with scientific terms and their perceptions were scientifically improved. On the other hand, it was often stated by the PSTs that DMMs can be used in learning activities like meetings-seminars-presentations, review of subjects and brainstorming as out of Science class. No study was found in the literature in relation to a certain part of the results of the study. Therefore, it is believed that the study conducted has contributed to the field. The use of Internet technologies like Coggle is of importance making it more convenient for students to interact simultaneously with other students (Nong, Pham, \& Tran, 2009), while helping the preparation of a collaborative mind map in learning-teaching environments.

In the light of the abovementioned findings, it can be said that mind mapping is a quite practical and effective technique for learner-centered active learning environments. According to students' opinions, mind maps can usually eliminate misconceptions and facilitate learning and reinforcement. Whereas, in terms of the interface used in mind mapping, DMMs -with its technological advantages- is seen to be of priority according to students' opinions. Within this framework, the opinions can be summarized under titles such as the possibility of adding various visual materials, ease of correction processes, ease of preparation and contribution to creative thinking and collaborative learning. Additionally, students noted that DMMs can be used for different lessons - subjects and activities such as meetings- seminars- presentations, etc. With 
its mentioned aspects as well as other characteristics, DMMs may be considered as an effective learning or evaluation tool, which can be used in almost every stage of education, active learning activities and technology-aided learning environments. It can also be said that the study has a guiding role for future studies to be carried out in a variety of disciplines. Additionally, the meta-analysis study carried out on the subject by Yesilpinar-Uyar and Doganay (2018) revealed that a total of 120 student-centered "strategies", "methods" and "techniques" were addressed in 105 articles, which were scanned in national and international databases (ERIC and SSCI) between the years 2016-2017, and only one of them referred to the mind map. Therefore, it is considered that there is not an adequate number of studies on the use of mind maps in learningteaching processes. Particularly, it is suggested that studies should be conducted on the advantages of DMMs are more effectively put in place in learning-teaching environments and the wider use of them.

Based on the results of this study, the implications can be made in relation to educational policy and instructional design. Although it is easy to apply DMMs at university level, it may be alarming to use it with students at earlier ages. Thus, for example in Turkey, school administration may restrict the use of mobile devices and applications by middle school students. These technologies can be used to assist the learning practices outside the school. In addition, the availability of this technology is getting more difficult in schools and regions with inadequate technological infrastructure.

It can be benefited from DMMs in the situations related to the 'teaching-learning process' and 'evaluation' components of the curriculum. Specifically, DMMs can be used as a technique within the scope of individual and, especially, collaborative learning to make learning permanent by enhancing interaction (with multimedia contents). Theoretically, this technique serves for a strategy that transforms the theoretical infrastructure of constructivist approach into practice (Dhindsa, Makarimi-Kasim, \& Anderson, 2011). Mind maps as an active learning tool in the student-centered learning environments (Rosciano, 2015) enable the learner to summarize the information, to understand the basic features of information at a conceptual level and to associate the information with many concepts. Additionally, thanks to their user-friendly interface, technology-based mind maps encourage the student to use the visual elements in the web environment freely and easily. Even though this situation makes a positive contribution to creativity ability, it is doubtful whether the opportunities provided by this technology offer an environment that completely enhances creativity. In this sense, the student can relate any concept to the (interdisciplinary) concepts in the curricula of different courses as well as the other concepts in the curriculum of the related course. This situation may strengthen the interrelation of the curricula with a holistic view.

The recent study is pioneer for usage of DMMs in the educational contexts to educators or scholars also have several limitations. First, in order to not correlational or experimental study, it does not offer causative reasons and empirical evidences for cognitive and affective features of the PSTs and the findings may be unsuited for generalization to different samples. Hence, further studies can focus on impact of the mind maps specially DMMs - on the variables such as learning performance, technology attitude, creativity in learning-teaching process. Furthermore, researchers should performed on 
different samples and grade levels in teacher education, because of small sample in this study. Second, Coggle was used as a tool in creating DMMs in this study. Unlike its advantages such as ease of use, allowing students to collaborate, visualization, the users do not sometimes act freely in creating their mind maps. Future studies are also needed to perform comparisons between Coggle and other digital mind maps in detail. Moreover, most of the universities around the world are carrying out their courses through distance education due to the recent COVID-19 pandemic. In this process, the need for and the importance of web 2.0 technologies such as Coggle is becoming more evident. Therefore, new studies on DMMs will be a useful resource for researchers and teachers.

\section{Acknowledgments}

This study is the extended and enhanced version of the paper titled "A Review on Opinions of Pre-service Teachers on the Web-Based Interactive Mind Mapping and Paper \& Pen Mind Mapping" which was presented as an abstract between dates of 10-17 December 2017 at the 3rd Cyprus International Educational Research Congress (CICER'17) and which is not included in the proceeding as full text.

\section{Conflicts of Interest}

All authors declare that they have no conflicts of interest associated with this paper.

All procedures performed in studies involving human participants were in accordance with the ethical standards of the institutional and/or national research committee and with the 1964 Helsinki declaration and its later amendments or comparable ethical standards.

Informed consent was obtained from all individual participants included in the study.

\section{References}

Abi-El-Mona, I., Abd-El-Khalick, F. (2008). The influence of mind mapping on eighth graders' science achievement. School Science and Mathematics, 108(7), 298-312.

Akinoglu, O., Yasar, Z. (2007). The effects of note taking in science education through the mind mapping technique on students' attitudes, academic achievement and concept learning. Journal of Baltic Science Education, 6(3), 34-43.

Aljaser, A. M. (2017). The effectiveness of electronic mind maps in developing academic achievement and the attitude towards learning English among primary school students. International Education Studies, $10(12), 80-95$.

Amar Singh, J. K. (2004). Effects of Mind Mapping Strategies on the Development of Writing Skills of Selected Form Three Students (Unpublished Master Thesis). Senate of University Putra, Malaysia.

Amin, A.M., (2005). Using graphic organizers to promote active e-learning. In P. Kommers \& G. Richards (Eds.), Proceedings of ED-MEDIA 2005-World Conference on Educational Multimedia, Hypermedia \& Telecommunications (pp. 4010-4015). Montreal, Canada: Association for the Advancement of Computing in Education (AACE). Retrieved August 6, 2018 from https : //www . learntechlib.org/primary/p/20707/ 
Aydogdu, S., Guyer, T. (2019). The effect of digital concept maps in online learning environments on students' success and disorientation. Malaysian Online Journal of Educational Technology, 7(1), s. 76-93. DOI:10.17220/mojet.2019.01.006

Babaoglu, G., Keles, O. (2018). Determination of 6th grade students' perceptions of the concepts of "star", "planet" and "moon, sun and earth". Karaelmas Journal of Educational Sciences, 6(1), 127-145. DOI: $10.17244 /$ eku.347791

Balim, A. G. (2013). Use of technology-assisted techniques of mind mapping and concept mapping in science education: a constructivist study. Irish Educational Studies, 32(4), 437-456.

Balim, A. G., Aydin, G., Turkoguz, S., Evrekli, E., Inel, D. (2011). Technologically supported mind map applications for science and technology teachers. The Western Anatolia Journal of Educational Sciences, 2(4), 91-100.

Beydogan, H. (2011). Effects of mind map supported cognitive preparation on expository writing. Journal of Kirsehir Education Faculty, 12(4), 1-23.

Bilasa, P. (2015). Instructional use of mind map in kindergarten. Journal of Research in Education and Society, 2(1), 49-67.

Boyson, G. (2009). The Use of Mind Mapping in Teaching and Learning. Retrieved from https : //b701d59276e9340c5b4dba88e5c92710a8d62fc2e3a3b5f53bbb.ssl.cf2.rackcdn. com/docs/Mind\%20Mapping\%20Evidence\%20Report.pdf

Brinkmann, A. (2003). Graphical knowledge display-mind mapping and concept mapping as efficient tools in mathematics education. Mathematics Education Review, 16, s. 35-48.

Buzan, T. (2005). Mind Map Handbook: The ultimate thinking tool. London: Thorsons.

Buzan, T. (2009). Mind Mapping : Kickstart your Creativity and Transform your Life. London: BBC Active

Buzan, T., Buzan, B. (1996). The Mind Mapping Book: How to Use Radiant Thinking to Maximize your Brain's Untapped Potential. New York: Penguin Group.

Buzan, T., Dottino, T., Israel, R. (2012). Grass Roots Leaders: The BrainSmart Revolution in Business. Hampshire: Gower Publishing Limited.

Buzan, T., Griffiths, C., Harrison, J. (2013). Modern Mind Mapping: For Smarter Thinking. Cardiff: Proactive Press

Chang, J. H., Chiu, P. S., Huang, Y.M. (2018). A sharing mind map-oriented approach to enhance collaborative mobile learning with digital archiving systems. International Review of Research in Open and Distributed Learning, 19(1), 1-24.

Chen, Z. (2010). The Study of Mind Mapping with Collaborative Learning (Unpublished Master Thesis). University of Wisconsin-Platteville, USA.

Coban, S., Selcuk Tokatli, E. (2017). The effect of mind mapping technique on students' achievements in music lesson and on their attitudes towards the mind mapping technique. Education and Science, 42(190), $423-435$.

Coggle. (2018). Coggle. Retrieved from https://coggle.it/about

Dhindsa, H.S., Makarimi-Kasim and Anderson, O.R. (2011), "Constructivist-visual mind map teaching approach and the quality of students' cognitive structures”, Journal of Science Education and Technology, Vol. 20 No. 2, pp. 186-200.

Edwards, S., Cooper, N. (2010). Mind mapping as a teaching resource. The Clinical Teacher, 7(4), 236-239.

Ekici, I.D. (2015). Determination of pre-service science teachers' perceptions about science through mind maps. Mehmet Akif Ersoy University Journal of Education Faculty, 1(34), 132-151.

Eppler, M. (2006). A comparison between concept maps, mind maps, conceptual diagrams and visual metaphors as complementary tools for knowledge construction and sharing. Information Visualization, 5(3), $202-210$.

Erdem, A. (2017). Mind maps as a lifelong learning tool. Universal Journal of Educational Research, 5(12A), 1-7.

Gelb, M. J. (1995). Thinking for a Change. New York: Harmony Books.

Gomleksiz, M. N., Yetkiner, A. (2012). The effects of using mind mapping in English language teaching on students' academic achievement, retention, views and attitudes towards English. Electronic Journal of Social Sciences, 11(40), 129-160.

Gomleksiz, M. N., Fidan, E. K. (2013). The effect of computer assisted mind mapping on students' academic achievement, attitudes and retention in science and technology course. Gaziantep University Journal of Social Sciences, 12(3), 403-426.

Hallen, D., Sangeetha, N. (2015). Effectiveness of mind mapping in English teaching among viii standard students. i-manager's Journal on English Language Teaching, 5(1), 45-50. 
Hidayati, N., Zubaidah, S., Suarsini, E., Praherdhiono, H. (2020). The Relationship between critical thinking and knowledge acquisition: The role of digital mind maps-PBL strategies. International Journal of Information and Education Technology, 10(2), s. 140-145. DOI:10.18178/ijiet.2020.10.2.1353

Jbeili, I. M. A. (2013). The impact of digital mind maps on science achievement among sixth grade students in Saudi Arabia. Procedia-Social and Behavioral Sciences, 103, 1078-1087.

Kansizoglu, H. B. (2014). Zihin haritası tekniği [Mind map technique]. In Gunes, Firdevs (Ed.), Öğretim İlke ve Yöntemleri. Ankara, Turkey: Pegem Academy

Karadeniz, O., Tangulu, Z., Faiz, M. (2013). The effects of using mind mapping technique in secondary 6.th grade social studies lesson to the students' academic achievements. The Black Sea Journal of Social Sciences, 5(8), 131-142.

Keles, O. (2012). Elementary teachers' views on mind mapping. International Journal of Education, 4(1), 93-100.

Keskinkilic Yumusak, G. (2013). THE effect of mind maps used in the science lesson to the achievement of the students. Journal of Research in Education and Teaching, 2(3), 1-5.

Khoo, A. (2014). I am gifted, so are you. Singapore: Marshall Cevendish Editions.

Krasnic, T. (2011). How to Study with Mind Maps: The Concise Learning Method. Alexandria, VA: Concise Books Publishing.

Liu, Y., Tong, Y., Yang, Y. (2018). The application of mind mapping into college computer programming teaching. Procedia Computer Science, 129, 66-70.

Madu B.C., Metu Ifeoma, C. (2012). Effect of mind map as a note-taking approach on students' achievements' in economics. Journal of Emerging Trends in Economics and Management Sciences (JETEMS), $3(3), 247-251$.

Mapman, M. (2013). Learn with Minmaps: How to Enhance your Memory, Take Better Notes, Bost your Creavity, and Gain an Edge in Work or School-Easily. River Styx Publishing Company.

Miles, M.B., Huberman, A.M. (1994). An Expanded Source Book Qualitative Data Analysis. London: Sage Publication.

Mohaidat, M. M. T. (2018). The impact of electronic mind maps on students' reading comprehension. English Language Teaching, 11(4), 32-42.

Nast, J. (2012). Idea Mapping: How to Access Your Hidden Brain Power, Learn Faster, Remember More, and Achieve Success in Business. New Jersey: John Wiley \& Sons, Inc.

Nilsson, M. (2002). Geometric Algebra with Conzilla Building a Conceptual Web of Mathematics, (Unpublished Master Thesis), Stockholms University, Sweden.

Nong, B. K., Pham, T., Tran, T. (2009). Integrate the digital mindmapping into teaching and learning psychology. In Proc., 13th UNESCO-APEID Int. Conf. on Education and World Bank-KERIS High Level Seminar on ICT in Education. Hangzhou, China: Hangzhou Department of Education and Xiacheng People's Government.

Novak, J. D. (2009). Learning, Creating, and Using Knowledge: Concept Maps as Facilitative Tools in Schools and Corporations. New York: Routledge.

Ozcakir Sumen, O., Calisici, H. (2016). Pre-service teachers' mind maps and opinions on STEM education implemented in an environmental literacy course. Educational Sciences: Theory \&Practice, 16, 459-476.

Ozdemir, A., Alaybeyoglu, A., Balbal, K. F. (2017). Teaching quadrangle subjects through mind mapping technique. Science, Education, Art and Technology Journal (SEAT Journal), 1(2), 45-51

Papushina, I., Maksimenkova, O., Kolomiets, A. (2017). Digital educational mind maps: A computer supported collaborative learning practice on marketing master program. In Auer, M., Guralnick, D., Uhomoibhi, J. (Eds.), Interactive Collaborative Learning. ICL 2016. Advances in Intelligent Systems and Computing, vol 544. Springer, Cham.

Rosciano, A. (2015). The effectiveness of mind mapping as an active learning strategy among associate degree nursing students. Teaching and Learning in Nursing 10(2), 93-99.

Sen, E. (2012). The Effect of the Mind Map Technique on the Development of Cognitive and Motor Skills of Students in Violin Lessons in Fine Arts and Sports High School (Unpublished Doctoral Thesis), Marmara University, Institute of Education Sciences, Istanbul, Turkey.

Shih, P. C., Nguyen, D. H., Hirano, S. H., Redmiles, D. F., Hayes, G. R. (2009). GroupMind: Supporting idea generation through a collaborative mind-mapping tool. In G. Hayes, S. H. Hirano, D. Nguyen, D. Redmiles \& P. Shih (Eds), Proceedings of the ACM 2009 International Conference on Supporting Group Work. New York: ACM Press, pp. 139-48.

Siwczuk, E. (2005). Mind maps: A creative thinking tool in information technology. Technical Sciences, 8, 313-326. 
Tungprapa, T. (2015). Effect of using the electronic mind map in the educational research methodology course for master-degree students in the faculty of education. International Journal of Information and Education, 5(11), s. 803-807.

Wang, W. C., Lee, C. C., Chu, Y. C. (2010). A brief review on developing creative thinking in young children by mind mapping. International Business Research, 3(3), 233-238.

Warwick, P., Kershner, R. (2006) 'Is there a picture of beyond?' Mind mapping, ICT and collaborative learning in primary science. In: P. Warwick, E. Wilson \& M. Winterbottom (Eds), Teaching and Learning Primary Science with ICT. Maidenhead: Open University Press, pp 108-127.

Williams, M. H. (2012). Physical webbing: Collaborative kinesthetic three-dimensional mind maps. Active Learning in Higher Education, 13(1), 35-49.

Willis, C. L., Miertschin, S. L. (2006). Mind maps as active learning tools. Journal of Computing Sciences in Colleges, 21(4), 266-272.

Yesilpinar Uyar, M., Doganay, A. (2018). The effect of student centered strategies, methods and techniques on academic achievement: A meta-analysis study. Mersin University Journal of the Faculty of Education, 14(1), 186-209. DOI:10.17860/mersinefd.334542

Yilmaz, G. (2012). Teaching of Polygons by Using Vee Diagrams and Mind Maps to Primary School 7th Class (Unpublished Masters Thesis), Kastamonu University Institute of Science, Kastamonu, Turkey.

Zampetakis, L. A., Tsironis, L., Moustakis, V., (2007). Creativity development in engineering education: The case of mindmapping. Journal of Management Development, 26(4), 370-380, DOI:10.1108/02621710710740110

Zipp, G. P. (2011). Using mind maps as a teaching and learning tool to promote student engagement, Faculty Focus. Retrived from

www. facultyfocus.com/articles/teaching-and-learning/using-mind-maps-as-a-teaching-and-learning-tool-to-promote-student-engagement

Ziyadi, A., Surya, E. (2017). Use of model mind mapping of motivation to improve student achievement in math class materials integer v elementary school 200201padangsidimpuan state. International Journal of Sciences: Basic and Applied Research (IJSBAR), 34(3), 124-133.

M. Debbag is an assistant professor in department of educational sciences at Bartin University, Turkey. Completed his Ph.D (Curriculum and Instruction) at Abant İzzet Baysal University, Bolu, and his master (Educational Technology) at Gazi University, Ankara. His areas of interest are distance education, educational technologies, teacher training and blended learning.

B. Cukurbasi is an assistant professor in department of computer technology at Manisa Celal Bayar University, Turkey. He received a Ph.D in Computer and Instructional Technologies Education from Sakarya University. His research interest lies in the distance education, flipped classroom, robotics, Internet technologies, instructional design and technology integration in education.

M. Fidan is an assistant professor in department of educational sciences at Bartin University, Turkey. He also works at Distance Education Application and Research Center. He received a Ph.D in curriculum and instruction from Bolu Abant Izzet Baysal University in Turkey. His research interests include distance education, augmented reality, hidden curriculum, curriculum evaluation, teacher education, instructional design and educational technologies. 